\title{
The Role of Silver Thiosulphate and Glutamine on Direct Organogenesis of Two Date Palm (Phoenix dactylifera L.) Cultivars
}

\author{
دورثايوسلفات الفضة والكلوتامين في تكوين الأعضاء المباشر لصنفين من نخيل \\ (Phoenix dactylifera L.) التمر فين
}

Saleh M. Bader, Hussam S. M. Khierallah*

State Board for Agricultural Research, Ministry of Agriculture, Baghdad.

* Horticulture Dep., College of Agriculture, University of Baghdad-Iraq

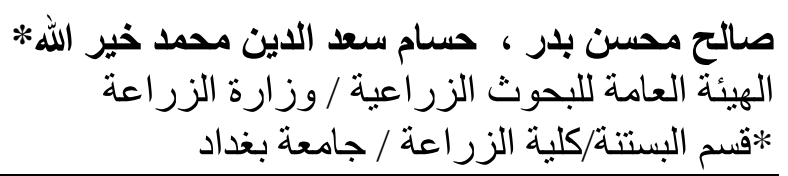

Abstract :

This study was conducted to examine the effect of silver thiosulphate (STS) and glutamine at various concentrations on direct organogenesis and shoots multiplication of date palm (Phoenix dactylifera $\mathbf{L}$.) Barhi and Maktom cvs. Shoot tip quarters were cultured in vitro on modified MS medium supplemented with 2.0 $\mathrm{mg} / 1$ 2ip, $1.0 \mathrm{mg} / 1 \mathrm{BA}, 1.0 \mathrm{mg} / 1 \mathrm{NAA}$ and $1.0 \mathrm{mg} / 1 \mathrm{NOA}$ with various concentrations of STS $(30,60,90$ and $120 \mu \mathrm{M})$ and glutamine at $(0.35,0.70,1.4$ and 2.1 $\mathrm{mM}$ ). The same concentrations were used in multiplication stage with medium supplemented with $4.0 \mathrm{mg} / 12 \mathrm{ip}, 2 \mathrm{mg} / 1 \mathrm{BA}, 1.0 \mathrm{mg} / 1 \mathrm{NAA}$ and $1.0 \mathrm{mg} / 1$ NOA. Results indicated that the addition of STS at $90 \mu \mathrm{M}$ and glutamine at $0.7 \mathrm{mM}$ gave the best result for adventitious bud formation after 16 weeks $(8.1$ and 9.4 buds per explant for Barhi and Maktom respectively). Subculturing of these buds on agitated liquid MS medium with $90 \mu \mathrm{M}$ STS and $1.4 \mathrm{mM}$ glutamine gave the highest average of shoots number (12.5 and 14.7 shoots for Barhi and Maktom respectively). Maktom cultivar produced more buds and shoots than Barhi irrespective of the level of STS and glutamine. Shoots were rooted and successfully transferred to soil. These results confirm the importance of supplementing plant culture media of date palm cvs. Barhi and Maktom with both silver thiosulphate and glutamine in order to optimize and improve the clonal propagation protocol for these two cultivars.

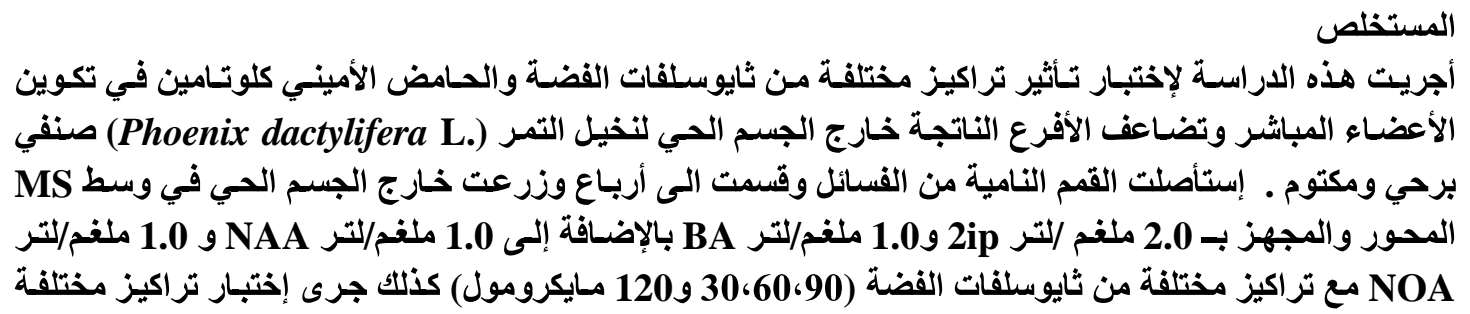




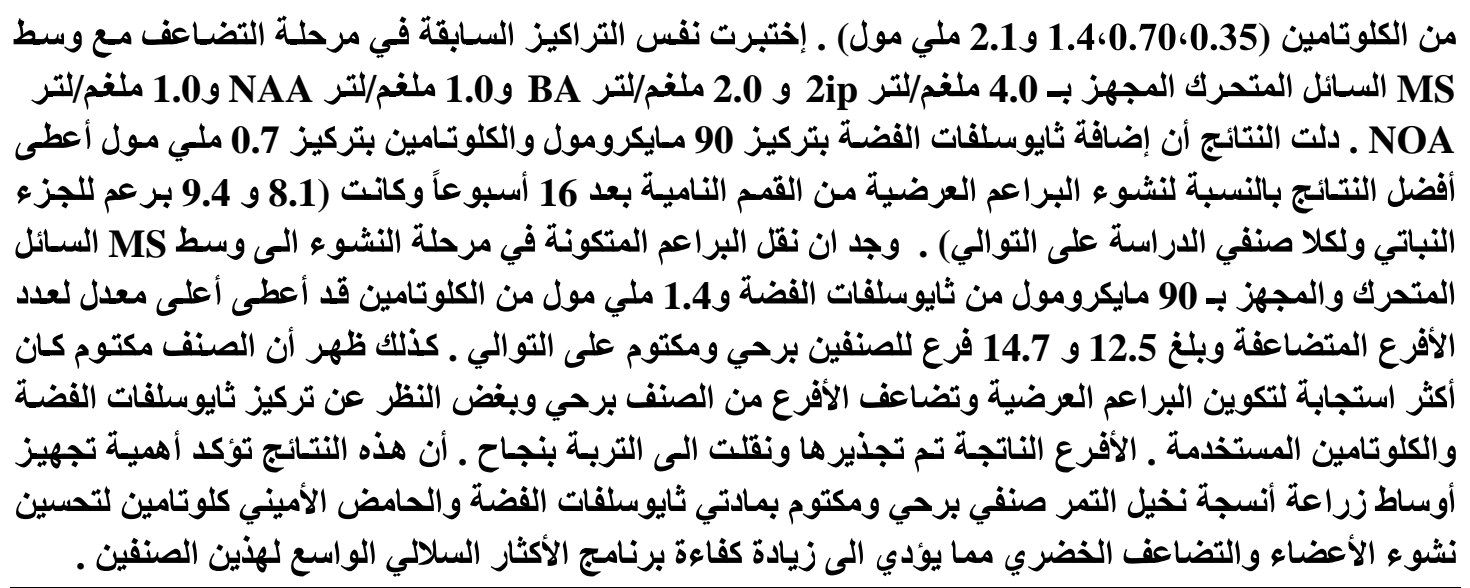

\section{Introduction :}

Date palm (Phoenix dactylifera L.) $(2 n=2 x=36)$ is a dioeciously, perennial, monocotyledon fruit trees that belong to the family of Arecaceae [1]. Dates are the major fruit crop of arid climate region in Middle East and North Africa. The heterozygosis' of date palm makes its progeny strongly heterogeneous [2]. Thus the propagation of date palm through offshoots is preferred over the seedlings. Since propagation through offshoots is slow and affected by their low survival rate, tissue culture of female plants has been preferred widely for mass production of true-to-type plants of elite varieties in demand.

Since the first attempts of date palm propagation by tissue culture [3,4] until now, two methods of propagation were developed, somatic embryogenesis and direct organogenesis. The production of somatic embryos from embryogenic callus was reported by many researchers $[5,6,7,8]$, as well as axillaries branching of shoot tip [9,10]. While [11.12] was success to enhance adventitious bud formation on shoot tip. Despite the fact that the first method is the most commonly used in commercial plant tissue culture labs, it involves the possibility of undesirable genetic variability. Direct organogenesis produces genetically identical, true to type plants; it presents an effective tool to the large scale vegetative propagation of date palm.

It is known that organ cultures as well as callus culture are able to produce the gaseous hormone ethylene [13]. Ethylene accumulation was found to be effected by tubes or flask closure method, gases exchange level and flaming. Ethylene accumulation causes culture growth inhibition [14]. Since silver Ions inhibit the action of ethylene, both silver thiosulphate (STS) $\left(\mathrm{Ag}_{2} \mathrm{~S}_{2} \mathrm{O}_{3}\right)$ and silver nitrate $\mathrm{AgNO}_{3}$ are effective in preventing ethylene action although the last is much more effective because it is readily translocated [15]. Glutamine was reported to stimulate growth and somatic embryos formation in date palm $[10,16]$. Therefore the aim of this study is to examine various concentrations of STS and Glutamine to stimulate the initiation and multiplication of adventitious buds directly from shoot tips of date palm cvs. Barhi and Maktom. 


\section{Material and Methods:}

1.Explants preparation and sterilization: Young offshoots of Barhi and Maktom cultivars (2-3 years old) were chosen and detached from mother palm. Offshoot's leaves were dissected acrepotaly until the shoot tips were appeared, shoot tips of $3 \mathrm{~cm}$ (apical meristem with soft inner leaves), were excised with immature fiber of $2 \mathrm{~cm}$ diameter and then applied in antioxidant solution consisted of $150 \mathrm{mg} / 1$ citric acid plus $100 \mathrm{mg} / 1$ ascorbic acid [17]. Explants were sterilized in $2.0 \%$ sodium hypochlorite solution containing eight drops of Tween-20 as emulsifier for 20 minutes with vacuum, and rinsed three times with sterile distilled water. Then transferred to Petri dishes and leaf primordia were removed except two pairs surrounding the apical meristem.

2. Initiation stage: The medium of initiation stage was composed of [18] (MS) salts plus the following in $\mathrm{mg} / 1$ : thiamine- $\mathrm{HC} 1$ 1.0; pyridoxine- $\mathrm{HCl} 1.0$; adenine sulfate $2 \mathrm{H}_{2} \mathrm{O}$ 50; myo-inositol $100 ; \mathrm{NaH}_{2} \mathrm{PO}_{4} \cdot 2 \mathrm{H}_{2} \mathrm{O}$ 170; sucrose 30000 activated charcoal 2000 and agar-agar 7000. The $\mathrm{pH}$ of the medium was adjusted to 5.7 with $0.1 \mathrm{~N} \mathrm{NaOH}$ or $\mathrm{HC} 1$, before the addition of agar. The media were dispensed into culture jars with $25 \mathrm{ml}$ in each one, then covered with polypropylene caps and then sterilized in autoclave under $121{ }^{\circ} \mathrm{C}$ and $1.04 \mathrm{~kg} / \mathrm{cm}^{2}$ for 15 minutes. Apical meristem were divided longitudinally into four equal segments and cultured in the jars aseptically under laminar air flow cabinet. Cultures were incubated in the dark, to reduce phenolic secretions from the explants for one month. The apical meristem quarters then removed and culture on media of the same composition supplemented with $2.0 \mathrm{mg} / 1$ isopentenyladenine (2ip), $1.0 \mathrm{mg} / 1$ benzyl adenine (BA), $1.0 \mathrm{mg} / 1 \mathrm{naphthalene}$ acetic acid (NAA) and $1.0 \mathrm{mg} / 1$ naphthoxyacetic acid (NOA) [19] with various concentrations of STS (30, 60, 90 and $120 \mu \mathrm{M})$. Cultures with the best response were transferred to media of the same composition as above with glutamine at $(0.35,0.70,1.4$ and $2.1 \mathrm{mM})$, to make better control of plant growth regulators concentrations, activated charcoal was changed by $2 \mathrm{~g} / \mathrm{l}$ of polyvenypyroledone (PVP). After that all cultures were incubated in culture room under low light intensity of 1000 lux for 16 hours daily and $27 \pm 1^{\circ} \mathrm{C}$ for four weeks. The reculture was conducted every four weeks for four times until the buds initiation in which data (number of forming buds) was recorded. The replicates were ten for each treatment.

3.Multiplication stage: The formed buds of the two cultivars were divided into small clumps, each one containing three buds, and cultured on medium of same composition except the hormonal addition. The same concentrations of STS and Glutamine were used in multiplication stage with agitated liquid MS medium supplemented with $4.0 \mathrm{mg} / 1$ 2ip, $2 \mathrm{mg} / 1 \mathrm{BA}, 1.0 \mathrm{mg} / 1 \mathrm{NAA}$ and $1.0 \mathrm{mg} / 1 \mathrm{NOA}$ [19]. The replicates were ten for each treatment. Cultures were incubated under same conditions as above. Reculture was carried out every four weeks, data (number of shoots) recorded after eight weeks. All the experiments were factorial and the experimental design used in this study was Complete Randomized Design (CRD), and wherever there was a significant effect, less significant difference (LSD) was used to compare among means at $5 \%$ level probability. 


\section{Result and Discussion:}

Effect of STS: Results shown in table (1) indicated that the addition of STS increased significantly the number of adventitious buds proliferated from shoot tip quarters for both cultivars. The highest number was achieved at $90 \mu \mathrm{M}$ of STS which gave 7.1 buds. Maktom explants produced significantly more buds 6.7 buds than Barhi 5.8 buds irrespective of the level of STS. The results indicated significant interaction between cultivars and concentrations of STS. The highest number was achieved at $90 \mu \mathrm{M}$ of STS which gave 6.8 and 7.3 buds for both cultivars respectively Fig (1). STS also had a significant effect on shoot multiplication after 8 weeks of culture on multiplication medium. Results shown in table (2) indicated that the addition of STS at $90 \mu \mathrm{M}$ to the culture medium increased significantly the number of adventitious shoots up to 10.3 for both cultivars. The addition of $120 \mu \mathrm{M}$ of STS caused significant reduction in shoots number comparing with $90 \mu \mathrm{M}$ of STS.

Table (1): Effect of various concentrations of silver thiosulphate (STS) on adventitious bud formation of date palm cvs. Barhi and Maktom after 8 weeks of culture on initiation medium.

\begin{tabular}{|c|c|c|c|}
\hline \multirow{2}{*}{$\begin{array}{c}\text { STS } \\
(\mu \mathrm{M})\end{array}$} & \multicolumn{2}{|c|}{ Cultivars } & \multirow{2}{*}{ Means } \\
\cline { 2 - 3 } & Barhi & Maktom & \\
\hline 0.0 & 6.8 & 8.6 & 7.7 \\
\hline 30 & 8.3 & 9.2 & 8.8 \\
\hline 60 & 9.4 & 9.4 & 9.4 \\
\hline 90 & 10.3 & 10.3 & 10.3 \\
\hline 120 & 9.1 & 9.2 & 9.2 \\
\hline Means & 8.8 & 9.3 & \\
\hline
\end{tabular}

L.S.D $(0.05)$ : Cultivars $=0.3$, STS Conc. $=0.4$, Cultivars $\times$ STS $=0.7$

Table (2): Effect of various concentrations of silver thiosulphate (STS) on shoots multiplication of date palm cvs. Barhi and Maktom after 8 weeks of culture on multiplication medium

\begin{tabular}{|c|c|c|c|}
\hline \multirow{2}{*}{$\begin{array}{c}\text { STS } \\
(\mu \mathrm{M})\end{array}$} & \multicolumn{2}{|c|}{ Cultivars } & \multirow{2}{*}{ Means } \\
\cline { 2 - 3 } & Barhi & Maktom & \\
\hline 0.0 & 4.8 & 6.2 & 5.5 \\
\hline 30 & 5.3 & 6.3 & 5.8 \\
\hline 60 & 6.3 & 6.9 & 6.6 \\
\hline 90 & 6.8 & 7.3 & 7.1 \\
\hline 120 & 6.1 & 6.8 & 6.5 \\
\hline Means & 5.8 & 6.7 & \\
\hline
\end{tabular}

L,S. $D_{(0.05)}$ : Cultivars $=0.3$, STS Conc. $=0.4$, Cultivars $\times$ STS $=0.6$

Maktom produced significantly more shoots (9.3 shoots) than Barhi (8.8 shoots) irrespective of the level of STS. The results also indicated significant interaction between cultivars and concentrations of STS in shoots multiplication. The highest number was achieved at $90 \mu \mathrm{M}$ of STS which gave 10.3 shoots for both cultivars Fig (2 and 3). The 
above results indicated that STS promote shoots regeneration and multiplication of date palm in vitro. This might be due to the role of silver ions which overcome the action and metabolism of ethylene [20]. Ethylene is known to inhibit and sometime stimulate in vitro growth and morphogenesis depending upon the species and culture stage [21].

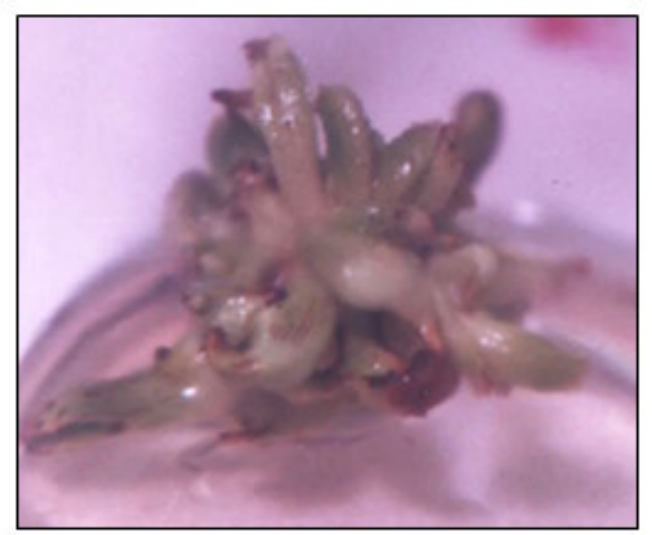

Fig (1) Shoot tip quarter of Barhi cultivar after 16 weeks of growing in initiation medium supplemented with $90 \mu \mathrm{M}$ of STS and $0.7 \mathrm{mM}$ of glutamine

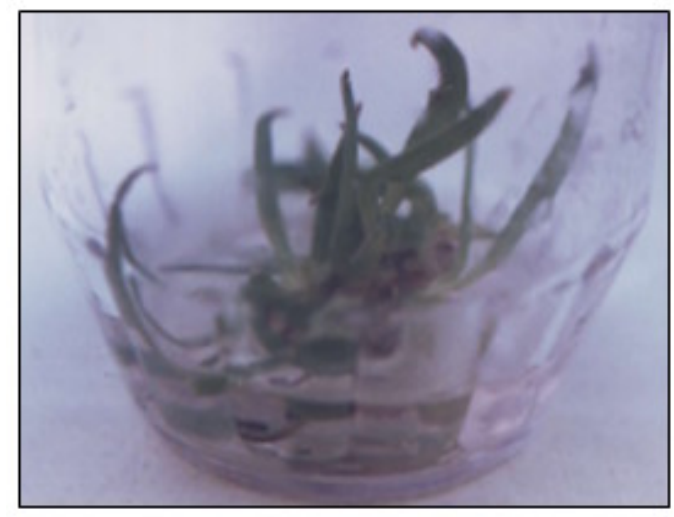

Fig (2) Shoots multiplication of Barhi cultivar after 8 weeks growing in shoots multiplication medium supplemented with $90 \mu \mathrm{M}$ of STS

The reference [22] reported that direct shoot formation on Begonia $\mathrm{x}$ richmondensis stem segments was inhibited by $2-20 \mathrm{mg} / \mathrm{l}$ ethephon and completely prevented by $200 \mathrm{mg} / \mathrm{l}$. In date palm tissue culture it was reported that $\mathrm{AgNO}_{3}$ increased embryogenic callus weight in the absence of cytokinin, similar effects were noted upon the numbers of embryos formed, although here the number was reduced by an increase in $\mathrm{AgNO}_{3}$ concentration [23].

Effect of Glutamine: Results shown in table (3) indicated that the addition of glutamine to the initiation medium supplemented with the best concentration of STS $(90 \mu \mathrm{M})$ increased significantly the number of adventitious buds proliferation from shoot tip quarters for both Barhi and Maktom cultivars. 
Table (3): Effect of various concentrations of glutamine on adventitious bud formation of date palm cvs. Barhi and Maktom (in presence of $90 \mu \mathrm{M}$ of STS) after 8 weeks of culture on initiation medium.

\begin{tabular}{|c|c|c|c|}
\hline \multirow{2}{*}{$\begin{array}{c}\text { Glutamine } \\
(\mathrm{mM})\end{array}$} & \multicolumn{2}{|c|}{ Cultivars } & \multirow{2}{*}{ Means } \\
\cline { 2 - 3 } & Barhi & Maktom & \\
\hline 0.0 & 6.8 & 7.3 & 7.1 \\
\hline 0.35 & 7.1 & 8.0 & 7.6 \\
\hline 0.70 & 8.1 & 9.4 & 8.8 \\
\hline 1.40 & 6.2 & 8.4 & 7.3 \\
\hline 2.10 & 4.5 & 6.2 & 5.5 \\
\hline Means & 6.6 & 7.9 & \\
\hline
\end{tabular}

L.S. D(0.05) $_{\text {: }}$ Cultivars $=0.3$, Glutamine Conc. $=0.4$, Cultivars $\times$ Glutamine $\stackrel{\square}{=} 0.7$

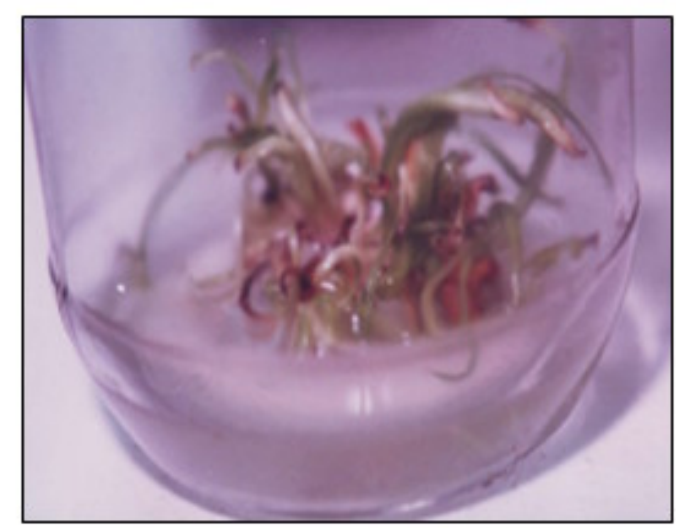

Fig (3) Shoots multiplication of Barhi cultivar after 8 weeks growing in Shoots multiplication medium supplemented with $90 \mu \mathrm{M}$ of STS and $1.4 \mathrm{mM}$ of Glutamine

The number of proliferated buds then reduced significantly with the increasing of STS concentrations over $0.7 \mathrm{mM}$. Fig (1 and 4). Maktom explants produced significantly more buds 7.9 buds than Barhi 6.6 buds irrespective of the level of glutamine. The results indicated significant interaction between cultivars and concentrations of glutamine. The highest number was achieved at $0.7 \mathrm{mM}$ of glutamine which gave 8.1 and 9.4 buds for both cultivars respectively. Results shown in table (4) indicated that the addition of glutamine increased significantly shoots multiplication after 8 weeks of culture on multiplication medium supplemented with various concentrations of glutamine. The number of shoots were increased by increasing glutamine concentrations up to 13.6 shoots at $1.4 \mathrm{mM}$ of glutamine then reduced significantly to 10.4 shoots at $2.1 \mathrm{mM}$. Maktom produced significantly more shoots (11.8 shoots) than Barhi (11.0 shoots) irrespective of the level of glutamine. The results indicated significant interaction between cultivars and concentrations of glutamine. The highest number was achieved at $1.4 \mathrm{mM}$ of glutamine which gave 12.5 and 14.7 shoots for both cultivars respectively. 
Table (4): Effect of various concentrations of glutamine on shoots multiplication of date palm cvs. Barhi and Maktom (in presence of $90 \mu \mathrm{M}$ of STS) after 8 weeks of culture on multiplication medium

\begin{tabular}{|c|c|c|c|}
\hline \multirow{2}{*}{$\begin{array}{c}\text { Glutamine } \\
(\mathrm{mM})\end{array}$} & \multicolumn{2}{|c|}{ Cultivars } & \multirow{2}{*}{ Means } \\
\cline { 2 - 3 } & Barhi & Maktom & \\
\hline 0.0 & 10.3 & 10.3 & 10.3 \\
\hline 0.35 & 10.8 & 11.0 & 10.9 \\
\hline 0.70 & 11.0 & 12.5 & 11.8 \\
\hline 1.40 & 12.5 & 14.7 & 13.6 \\
\hline 2.10 & 10.5 & 10.3 & 10.4 \\
\hline Means & 11.0 & 11.8 & \\
\hline
\end{tabular}

L.S. $D_{(0.05)}:$ Cultivars $=0.3$, Glutamine Conc. $=0.5$, Cultivars $\times$ Glutamine $=0.8$

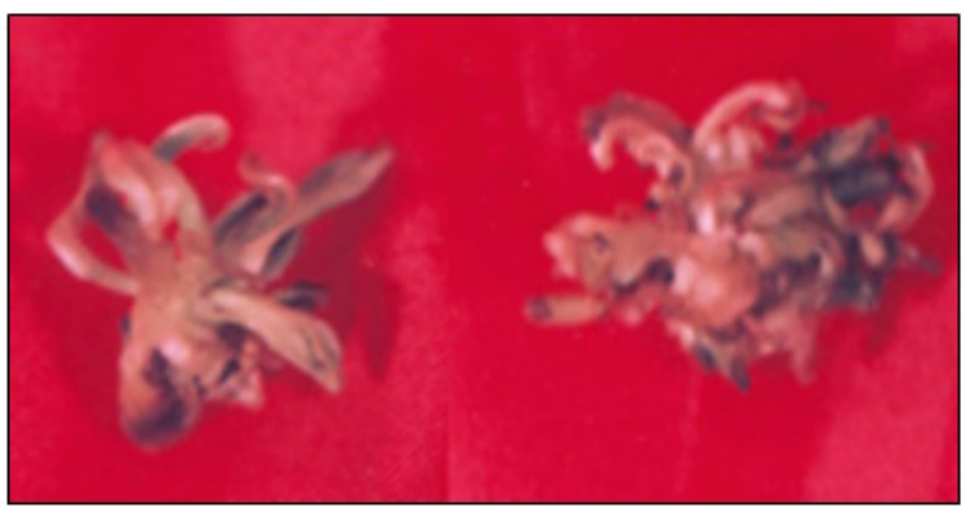

Fig (4) Shoot tip quarter of Maktom cultivar after 16 weeks of growing in initiation medium supplemented with A: control B: $90 \mu \mathrm{M}$ of STS and $0.7 \mathrm{mM}$ of glutamine

These results revealed the effectiveness of glutamine to promote shoots regeneration and multiplication of date palm in vitro culture. This might be due to the rapid uptake of reduced nitrogen which provided by this amino acid [24]. Glutamine and glutamic acid are directly involved in the assimilation of $\mathrm{NH}_{4}{ }^{+}$. A direct supply of these amino acids should therefore enhance the utilization of both nitrate and ammonium nitrogen and its conversion into amino acids [15]. The addition of glutamine in date palm tissue culture media increased callus quality and somatic embryos formation [16], shoots vegetative multiplication [10] and adventitious bud multiplication [25]. 


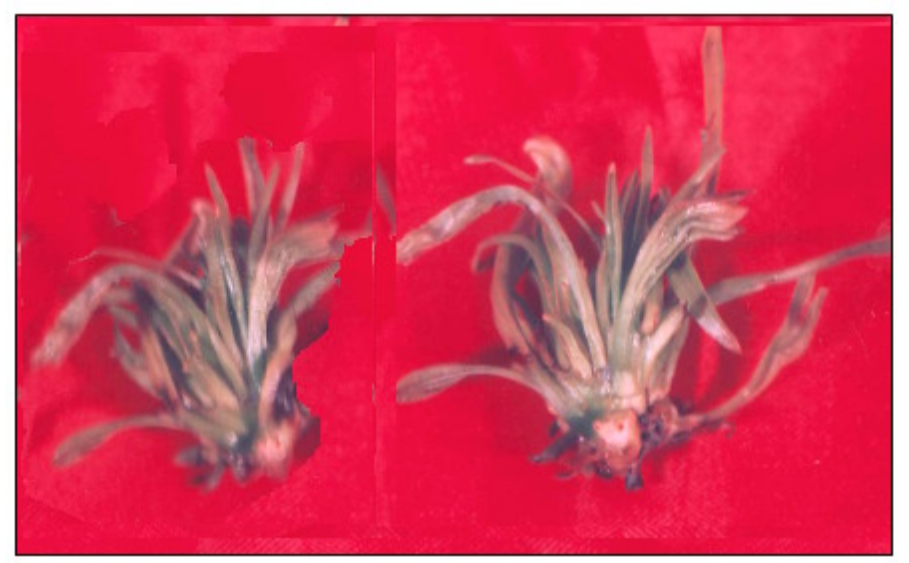

Fig (5) Shoots multiplication of Maktom cultivar after 8 weeks growing in Shoots multiplication medium supplemented with A: control B: $90 \mu \mathrm{M}$ of STS and $1.4 \mathrm{mM}$ of Glutamine

In conclusion, the positive role of STS and glutamine in this study leads to the recommendation to include them in the commercial micropropagation programs of these two cultivars.

\section{References}

1. Barrow, S. 1998. A monograph of phoenix L. (palmae: Coryphoideae). Kew Bull., 53: 513-575.

2. Munier, P. 1981. Origine de la culture sur palmier dattier et sa propagation en Afrique. Fruits, 36 (7-8): 437-450.

3. Schroeder, C.A. 1970. Tissue culture of date shoots and seedlings. Date Growers Inst. Rep., 47:25-47.

4. Reuveni, O., Adato, Y. and Kipnis, H.L.1972. A study of new and rapid methods for the vegetative propagation of date palms. Date Growers Inst. Rep., 49: 17 -24.

5. Reuveni, O. 1979. Embryogenesis and plantlet growth of date palm (Phoenix dactylifera L.) derived from callus tissues. Plant. Physiol., 63. 138.

6. Mater, A.A. 1983. Plant regeneration from Callus culture of phoenix dactylifera L. Date Palm J., 2:57-73.

7. Omar, M.S. 1988. Callus initiation, asexual embryogenesis and plant regeneration in (Phoenix dactylifera L.) Date Palm J.6:265-275.

8. Al-Musawi, A.H. 2001. Effect of auxin, cytokinine, and activated charcoal on embryo development and germination of date palm (Phoenix dactylifera L.) cultured in vitro. Basrah Date Palm Res. J.1: 8 - 18.

9. Tisserat, B. 1984. Propagation of date palm by shoot tip culture. Hort Science, $19: 230$ -231 .

10. Hameed, M.K. 2001. Propagation of some date palm (Phoenix dactylifera L.) cultivars through tissue culture technique. $\mathrm{PhD}$ thesis (in Arabic). Iraq.

11. Al-Maari, K.W. and Al - Ghamdi, A.S. 1997. Micro- propagation of five date palm cultivars through in vitro axillary buds proliferation. Du. J. Agri. Sci., 13 : 55 - 71. 
12. Al-Khateeb, A.A., Abdalla, G.R., Dinar, H.M., Al-Khateeb, A.A., and Abugulia, K.A. 2002. Auxin: cytokinine interactions in the in vitro Micropropagation of date palm (Phoenix dactylifera L.) Egypt. J. Appl. Sci ., 17 (10): 409 - 415.

13. Mele, E., Messeguer, J. and Camprubi, P. 1982 Effect of ethylene on carnation explants grown in sealed vessels. pp. 69-70 in Fujiwara (ed.)

14. Pierik, R.L. 1999. In Vitro Culture of Higher Plants. Third Edition. Martinus Nijn off Publishers. Netherlands.

15. George, E.F and Sherrington, P.D. 1993. Plant Propagation by Tissue Culture. Second Edition. Exegetics Ltd. England.

16. Jasim, A.M. and Saad, A.A. 2001. Effect of some media component on growth and somatic embryos formation and germination of date palm (Phoenix Dactylifera L.) cultured in vitro. Basrah Date Palm Res. J; 1:1-7.

17. Tisserat, B.1991. Clonal propagation of palms. Plant tissue culture manual, C2 : 1- 14.

18. Murashige, T. and Skoog, F. 1962. A revised medium forrapid growth and bioassays with tobacco tissue culture. Physiol. Plant., 15: 473 - 497.

19. Khierallah, H. S. and Bader S. M. 2007. Micropropagation of Date Palm (Phoenix dactylifera L.) var. Maktom through Direct Organogenesis

20. Acta Hort., Vol. 736: 213-224.

21. Beyer, E.M. 1979. Effects of silver ion, carbon dioxide and oxygen on ethylene action and metabolism. Plant Physiol., 63:169-173.

22. Kumar, P.P., Lakshmins, P., Thorp, T.A., 1998. Regulation of morphogenesis in plant tissue culture by ethylene. In Vitro Cell. Dev. Biol. Plant, 34:94-103.

23. Ringe, F. 1972. Forderung der Zellproliferation unter der Einwirkung von 2Chlorathylphosphorsaure bei Explantaten von Begonia $\mathrm{x}$ richmondensis in steriler Kultur. Z. Pflanzenphysiol. (Abst) 67:45-48.

24. Al- Khayri, J.M. and A. M. Al- Bahrany. 2001. Silver nitrate and 2-isopentyladenine promote somatic embryogenesis in date palm (Phoenix dactylifera L.). Scientia Hort., 89:291-298.

25. Abo El-Nil, M. 1986. the effect of amino acid nitrogen on growth of date palm callus. $2^{\text {nd }}$ Symp. Date Palm, King Faisal Univ., Saudi Arabia, pp. 59-65.

26. Khierallah, H. S. 2007. Micropropagation of two date palm (Phoenix dactylifera L.) cultivars using inflorescences and study the genetic stability using AFLP markers. PhD thesis (in Arabic). Iraq. 